\title{
O homem e o absurdo: aproximações entre O mito de Sísifo, de Albert Camus, e Estrela polar, de Vergílio Ferreira
}

\author{
The man and the absurd: relations between The myth of Sisyphus, by Albert Camus, \\ and Estrela polar, by Vergílio Ferreira
}

\author{
AMANDA BARROS DE MELO \\ Universidade Federal de Pernambuco - Recife - Pernambuco - Brasil \\ ANTONY CARDOSO BEZERRA \\ Universidade Federal Rural de Pernambuco/Universidade Federal de Pernambuco - Recife - Pernambuco - Brasil
}

-

\begin{abstract}
Resumo: Numa leitura paralela entre $O$ mito de Sísifo, de Albert Camus, e Estrela polar, de Vergílio Ferreira, verifica-se em que sentidos o escritor português configura ficcionalmente a ideia do homem absurdo, problematizada por Camus em seu ensaio. Com recorrência a elementos da fortuna crítica do romance, acompanha-se o atormentado percurso da personagem Adalberto, protagonista e narrador de Estrela polar, em suas tentativas goradas tanto de compreender-se a si próprio, quanto de comungar com os que estão à volta. Sem que se enfatize o signo da influência, vem-se a perceber que muitos dos problemas levantados pelo autor francófono materializam-se em Adalberto, fator que faz com que os dois textos se iluminem mutuamente.

Palavras-chave: $O$ mito de Sísifo; Albert Camus; Estrela polar; Vergílio Ferreira; Absurdo

Abstract: This article intends to verify how Portuguese writer Vergílio Ferreira fictionalizes, in his novel Estrela polar, the idea of absurd man, which was previously focused by Albert Camus in The myth of Sisyphus. By considering aspects of Estrela polar as analyzed by other critics, the article follows the path of Adalberto, both narrator and character of the novel; mainly, his unsuccessful attempts of understanding himself and the others. Putting the dimension of influence apart, it is possible to perceive that many issues raised by Camus are composed in Adalberto, which makes possible a better comprehension of both works.
\end{abstract}

Keywords: The myth of Sisyphus; Albert Camus; Estrela polar; Vergílio Ferreira; Absurd

L'absurde est la grâce des gens qui sont fatigués.

Charles Baudelaire

Em $O$ mito de Sísifo, obra ensaística publicada em 1942 pelo escritor franco-argelino Albert Camus, é possível encontrar a origem do pensamento da absurdidade do mundo conforme a concebeu o autor. Um biógrafo literário de Camus, Roger Grenier, foi capaz de identificar, na obra, um certo "aspecto filosófico" (GRENIER, 2009, p. 94), em que pese a reconhecer que o próprio Camus rechaçasse um tal estatuto: "Em mais de uma oportunidade, ele [Camus] insistirá na ideia de não ser um filósofo. Ele descreve a atitude do homem uma vez confrontado com o absurdo da condição humana." (GRENIER, 2009, p. 124.) ${ }^{1}$ No livro em questão, o que se

\footnotetext{
1 Traduziram-se ao Português todas as citações de textos em língua
} estrangeira. parece pôr em pauta, antes de uma questão essencialmente filosófica, é um mal do espírito. O mito de Sísifo passou por um longo período de amadurecimento, em sua maior parte, mergulhado nas agruras decorrentes da $2^{\text {a }}$ Guerra Mundial, que o autor de $O$ Estrangeiro teve ensejo de vivenciar muito proximamente, ainda que, sobretudo, na condição de testemunha. Já em 1936, há registros da redação do ensaio sobre a absurdidade, mas só em fevereiro de 1941, na Oran natal, poderá, o escritor, dar por encerrado o seu trabalho (GRENIER, 2009, p. 126).

$O$ mito de Sísifo divide-se em quatro partes, a saber: (1) "Um raciocínio absurdo"; (2) "O homem absurdo"; (3) "A criação absurda"; e (4) "O mito de Sísifo", sendo esta a parcela mais breve do volume. Conforme sustenta ao longo dos ensaios, Camus percebe a busca pelo sentido 
da vida como a mais premente das perguntas, razão pela qual inicia a obra tratando do problema do suicídio: "Julgar se a vida vale ou não vale a pena ser vivida é responder à pergunta fundamental da filosofia" (CAMUS, 2010, p. 19). Segundo ele, não parece haver uma lógica na existência, e o sentimento do absurdo nasce justamente dessa confrontação entre o desejo do homem por clareza e razão, confrontado com a ausência de respostas uma vez inserido no mundo. O sentimento do absurdo resulta desse divórcio entre o homem e o mundo. Não há uma definição do absurdo, mas um sentimento do absurdo que seria mais amplo e vivo.

Diante do juízo do ensaísta, segundo o qual o que interessa "não são tanto as descobertas absurdas", mas, sim, "suas consequências" (CAMUS, 2010, p. 29), acredita-se, no presente artigo, ser viável relacionar a discussão entabulada pelo autor francófono à expressão ficcional da condição humana conforme configurada pelo romancista português Vergílio Ferreira em um dos seus livros do dito "ciclo existencialista", que é Estrela polar (1962). ${ }^{2}$ Não se intenta propriamente aferir em que medida Ferreira - em caráter inegável, bebedor de fontes francesas (leiam-se Jean-Paul Sartre, André Malraux e o próprio Camus), mas não apenas - segue ou não uma possível cartilha de seus inspiradores e se (ou como) materializa um eventual aprendizado no romance em questão. Visa-se, isto sim, à promoção de uma leitura crítica que articule a problematização elaborada por Camus em $O$ mito de Sísifo com a narrativa ficcional portuguesa, na medida em que esta traduz as inquietações da subjetividade humana em seu estar no mundo, tanto nas relações com o outro, como consigo mesmo. A exemplo do que se vê em relação a Camus - não raro tachado existencialista quando nem ele, nem Sartre (ícone da corrente) assim pensam (cf. GRENIER, 2009, p. 132-133; e BARRETO, 1991, p. 20-21) -, Ferreira parece escapar à vinculação monolítica a determinada prática filosófica; no caso, tanto àquela preconizada por Heidegger quanto à sartriana. $\mathrm{O}$ autor lusitano expõe seu rechaço a classificações e, especialmente, à de existencialista, afirmando que a corrente em questão "sofre a ameaça do ridículo com o ter um rótulo, ou seja, um modo de se anunciar publicamente" ([19 ] , p. 66). Considerando essa condição, o presente artigo objetiva, longe de enquadrar os dois autores numa categoria (por exemplo, de escritores do absurdo), evidenciar, a partir dos textos, as questões e as consequências do sentimento do absurdo proposto por Camus e de sua convergência na exposição humana no interior de uma produção ficcional, no caso, o romance Estrela polar.

Ferreira, como se indiciou em nota, iniciou-se, de algum modo, no movimento neorrealista português - no juízo de Mendonça (1978, p. 7), como uma manifestação da "pressão do tempo", ou "Zeitgeist". Entrementes, logo veio a afastar-se da tendência, por acreditar que, numa dimensão do realismo imediato, a problemática social do movimento era

[...] descritiva e limitada, esquecia-se um pouco do destino do próprio artista e desenvolvia-se de algum modo à superfície da vida. [...] A uma temática de algum modo circunstancial, eu vim assim a preferir uma mais duradoura [...], eu preferi a defrontação do homem com a sua própria condição. [...] A uma obra, em suma, que apenas informasse eu preferi a que se decidisse pela perturbação [...]. (FERREIRA, 1987, p. 24)

Não se pretende entrar no mérito do reducionismo dos reparos feitos por Ferreira, pois tal discussão afastaria o artigo de seus propósitos. ${ }^{3} \mathrm{O}$ que cabe assinalar, entretanto, é a dimensão do projeto encampado pelo autor, traduzido na constituição marcantemente subjetiva e metafísica de sua obra, como fator que o teria afastado dos ideais por ele identificados nas práticas neorrealistas.

É verdade que as personagens de Ferreira não tendem a explicitar um envolvimento político, embora, negando um apelo engajado (no sentido de uma intervenção direta no mundo circundante), também estejam se posicionando politicamente. ${ }^{4}$ Tal condição se pode respaldar, mais uma vez, pelo discurso manifesto do escritor, conforme exposto no "Prefácio do Autor" de Vagão " J": "É aliás absurdo considerar-se a luta de classes, porque ela é já

2 Dividir a obra de um autor em fases sempre é reduzi-la. Apesar disso, julga-se que tal classificação, no caso específico de Ferreira, sirva como adjuvante para entender as mudanças (ideológicas e estruturais) por que passa a sua produção literária, iniciada com $O$ caminho fica longe (1943), livro de recorte neorrealista, até à "conversão" aos referenciais heideggerianos e existencialistas que se pode flagrar em Mudança (1949); plenamente configurado no que Mendonça (1973, p. 163) reputa como os "três mais importantes romances": Aparição (1959), Estrela polar e Alegria breve (1965).

3 Como bem coloca Mário Dionísio, um dos principais teóricos do Neorrealismo, este "[...] não compreende o homem desligado da vida social e encara-o, portanto, de um ângulo diferente de observação, mas deseja também o maior aprofundamento do indivíduo. Serve-se de todas as descobertas fecundas do interiorismo e apenas rejeita o que lhe parece tão só fruto de uma imaginação sem controle." (DIONÍSIO apud TORRES, 1977, p. 62)

4 Pautando a sua discussão no que diz respeito à Literatura de Expressão Francesa, Benoît Denis reconhecerá que, em sentido lato, "[...] toda obra literária é em algum grau engajada, no sentido em que ela propõe uma certa visão de mundo e que ela dá forma e sentido ao real." (DENIS, 2002:10) De outro lado, se assim pensasse, a Crítica Literária depararia com uma espécie de não definição, em que escritores com muito pouco de comum entre si seriam colocados dentro de uma mesma esfera. Por essa razão, pensar-se numa literatura de engajamento como aquela que tem um alcance político manifesto ou que, noutros termos, "sem renunciar a nenhum dos seus atributos [estético-literários], seja parte integrante do debate sociopolítico" (DENIS, 2002, p. 22) implicará não no estabelecimento de uma História Política da Literatura; antes, no inquérito às reflexões do autor literário acerca da inserção do político em sua obra (DENIS, 2002, p. 12). De certa maneira, o que está em pauta é também uma questão de projeto artístico (que nem sempre se concretizará literariamente); e, nesse sentido, não é devaneio referendar a visão que Ferreira tem da própria produção. 
a expressão de uma oposição mais radical. Que ela seja a expressão mais importante a se considerar [...] - é talvez de admitir. Mas não que a essa luta a expliquemos por si própria" (FERREIRA, 1974, p. 25-26) De certa maneira, a natureza das reflexões suscitadas em Estrela polar representam a negativa de Ferreira em privilegiar o que entende como social; e o absurdo, conforme se tenta demonstrar nesta investigação, é uma tradução impossível das inquietações existenciais do homem.

A propósito da problemática do absurdo, Camus afirma, em $O$ mito de Sísifo, que "em toda parte o absurdo nasce de uma comparação", nasce como uma "confrontação e uma luta sem trégua" (CAMUS, 2010, p. 41-42). Ora, para um texto que se pretende não filosófico, não apenas a menção a vários pensadores se mostra como expediente que aproxima o ensaio da filosofia, mas também o modus operandi - a prática da comparação, que remonta à filosofia pré-socrática (cf. BORNHEIM, 2007). A partir da premissa camusiana, convergente com a exposição ficcional do absurdo da vida, pode-se verificar que, em Estrela polar, há uma clara confrontação do protagonista, Adalberto, com seu mundo, amores, família, colegas e consigo mesmo. O mais alto patamar do absurdo se materializa na personagem e, por extensão, no triângulo de desejo completado pelas irmãs Aida e Alda. ${ }^{5}$

Narrado em modo autodiegético e em analepse (ainda que os tempos tendam a se confundir no plano narrativo), a narrativa do romance se configura como uma espécie de relato de memórias por vezes confusas e desordenadas, que permite acompanhar-se a sucessão dos eventos que levaram Adalberto até o crime que o levou para a prisão, de onde escreve o relato à memória de sua mãe morta. Aqui, não passa despercebido, afinal, um primeiro indício absurdo, de vez que não se escreveria um relato a uma morta. Nisso, pode-se observar uma aproximação com a criação absurda de Camus, para quem o escritor experimenta uma "felicidade metafísica em sustentar a absurdidade do mundo [...]; o deleite absurdo por excelência é a criação" (CAMUS, 2010, p. 97). Na tentativa de dizer algo que não se esgota em palavras, ou insistir em verbalizar as sensações mais profundamente inomináveis, o escritor e suas personagens se entregam ao jogo absurdo da existência. Tal é a perplexidade de

\footnotetext{
O estatuto das irmãs ditas gêmeas Aida e Alda é matéria para muitas discussões da crítica, seja de sua efetiva existência como duas, seja, também, de sua gemeidade. Para se ficar em dois exemplos, tem-se Paiva e Mendonça. Aquele, ao apresentar a sinopse da história, diz: "Adalberto apaixona-se por Aida, que tem uma irmã gêmea (?) chamada Alda, extraordinariamente parecida com ela." (PAIVA, 1984, p. 174) Já o segundo crítico observa: “[...] Aida/Alda, irmãs hipoteticamente gêmeas [...]. [A] ambiguidade das duas mulheres proporciona todo o esquema 'operatório' da obra [...]." (MENDONÇA, 1966, p. 128) No próprio discurso ficcional, patenteiam-se essas dubiedades, como no momento em que Faustino explica a Adalberto a condição de ambas (FERREIRA, 1992, p. 49-50).
}

Adalberto, que não consegue entender sequer a utilização de nomes próprios:

[...] Conheces-me pelo nome impessoal da lei (ou pelo que há de mais impessoal em mim?). Um nome exprime-nos como uma senha. Um nome. E imprevistamente alguma coisa de mim aí se estabelece, e é eu desde onde? Porque o meu "eu" verdadeiro, a minha fulguração não tem nome... (FERREIRA, 1992, p. 15)

A personagem parece completamente alheia à lógica habitual - ou pelo menos, descrente de seus mecanismos -; afinal, como o inominável caberia numa nomenclatura? O absurdo da linguagem e da comunicação também se coloca como uma temática em Estrela polar, desde a procura pela palavra exata, que parece não vir para expressar o mais recôndito do "eu" de Adalberto e de sua memória, até uma possível incompreensão presente em alguns diálogos com outras personagens. Isso porque, no diapasão que regula a narrativa, as verdades profundas e o apelo do sangue só se explicam pela linguagem da loucura.

Num de seus devaneios pela obscuridade da memória, ainda no início do romance, Adalberto se indaga: "Mas que escrevo? Que digo? Estes muros de silêncio ecoam-me a loucura. E todavia porque o pensei, o desejei, esse absurdo de uma comunicação, esse..." (FERREIRA, 1992, p. 35). É útil perceber que o próprio romancista, em Pensar (cujo cunho não é ficcional), pronuncia-se sobre o apelo ao silêncio: "O romance, por exemplo, como ser-nos tolerável, a menos que fale disso, do silêncio?" (FERREIRA, 1998, p. 83). A tentativa de comunicação entre os seres se apresenta como algo truncado e dificultoso, numa espécie de solidão a dois:

Até que um dia lhe falei, oh, não - que dissemos nós? Havia palavras avulsas entre os dois, mas estávamos em silêncio. Tomei-te a mão devagar, saímos para a cidade, naquela ronda sem fim que tantas vezes havíamos de repetir. Vagueamos pelas ruas desertas, olhamos as estrelas ao alto. - É tão duro estar só - disse eu. E não me lembro de termos dito mais nada. (FERREIRA, 1992, p. 36)

Nesse ponto da narrativa, Aida é dada ao conhecimento; é dela que o narrador fala no trecho acima. Mas, antes mesmo de manter contato com a jovem, Adalberto revela à mãe morta: "As razões são sempre póstumas ao que somos, como um ritual de mortos. Quando namorei a Adélia, de que te mostrei o retrato..." (FERREIRA, 1992, p. 10) Nessa sequência, intercala-se outra memória de quando Adalberto ia visitar a mãe em Penalva, uma cidade de tinta; o relato de uma memória partida perdura até ao fim da narrativa, talvez exigindo 
do leitor uma maior atenção para compreender do que se trata em cada momento. Conforme sinalizado, o tempo da narrativa é inconstante e confuso, haja vista esta se configurar como uma sucessão de lembranças, inclusive de algumas personagens que estão vivas em discurso, mas já morreram "fisicamente", como num ritual de mortos que possam explicar suas razões. ${ }^{6}$ Importa lembrar que a narrativa começa do fim para o início, também mesclando os momentos e nem sempre atando as duas pontas. No nível do discurso ficcional, isso se explica pela condição do narrador; no nível da obra, o procedimento acentua a absurdidade que integra o projeto autoral. Prosseguindo na descrição de sua relação com Adélia, Adalberto conta à mãe:

[...] Te contei tanta coisa infantil e amável, e que tu ouviste risonha, de certo por haver quem aprovasse a obra feita por ti, que era eu, [...] quando ela me deixou, o que se perturbou em mim não foi só o que... não foi só essa parte que se relacionava com ela. Tudo o mais se perturbou, tudo o mais [...] tudo o que me interessasse para a vida foi uma náusea sem fim: toldava-me um apelo de não sei quê, e o desastre amoroso foi-me assim um bom pretexto para me nausear de tudo. (FERREIRA, 1992, p. 11)

A personagem Adélia não voltará a ser mencionada na narrativa. Em que pese a isso, essa mínima descrição é muito fecunda para a compreensão das motivações de Adalberto, pois ele, condenado por um crime, em algum momento tinha sido tocado por coisas "infantis e amáveis" numa relação a dois; o abandono, entrementes, perturba-o inexoravelmente, causando uma náusea de tudo. Vê-se que a impossibilidade amorosa é um fulcro temático do romance, que se converte num combustível à dimensão do absurdo. Para Camus, "quanto mais se ama, mais se consolida o absurdo" (CAMUS, 2010, p. 75), e Adalberto parece, nas suas idas e vindas sentimentais e existenciais, avizinhar-se de tal condição.

O narrador inicia o romance contando que está indo visitar a mãe em Penalva, ambiente da infância. É uma localidade que parece ter vida própria na consciência de Adalberto, até porque a natureza e o clima da cidade

\footnotetext{
Importa perceber que, mesmo numa abordagem de raiz semióticoestrutural, mais urgente que o encadeamento de eventos num todo lógico à superfície do texto é perceber o que os condiciona. Nas palavras de Segre, "Reconstruir uma sucessão de acontecimentos (a fabula) não significa reconstruir suas motivações, muitas vezes impalpáveis, remotas, oblíquas. Tanto é verdade que a fabula pode ser - e de fato sempre é - um resumo; mas o conjunto das motivações é tão complexo que somente o texto em sua totalidade pode indicá-lo. $\mathrm{O}$ texto resiste invicto às nossas agressões, cujo melhor êxito pode apenas ser o fato de fazê-lo falar." (SEGRE, 1986, p. 40). Ora, não é sem razão o desconcerto da enunciação de Adalberto, atormentado pela sua perplexidade diante da própria existência e, ainda mais, recuperando eventos que, mesmo explicando sua situação presente no plano social, não o fazem em relação ao seu âmago.
}

também parecem adequar-se à vida interior conturbada da personagem; ou, melhor dizendo, são uma projeção (no tempo e no espaço) dessa inquietação. Lá, quase sempre faz frio, e a rua em que Aida, Alda e a família moram também se chama Inverno... Adalberto descreve com riqueza de detalhes os muros da cidade, o prédio em que morava, no sétimo andar, a livraria que herdou do pai e a ausência de vida das ruas: "Quem é que lê em Penalva? Quem é pessoa nesta cidade abandonada e à espera ainda do que já esqueceu? - muros negros com uma eternidade sem homens nem deuses..." (FERREIRA, 1992, p. 37). Esse será o cenário de quase toda a história, com exceção de uma viagem à praia e da própria cela de Adalberto, que não se sabe onde fica.

Em suas memórias, a intranquila personagem remete às constantes caminhadas pelas ruas de Penalva como um hábito, quase uma regra, talvez uma reação ao fato de estar presa; e a cidade parece uma extensão de si e de sua prisão. Tanto assim é que chega a dizer: "É estranho que eu fale da livraria, da cidade, como de um mundo desabitado. Mas é na realidade assim que me parece." (FERREIRA, 1992, p. 92) O descompasso com o mundo ao redor é evidente na perspectiva do narrador:

A minha vida é só uma, não tem princípio nem fim, sou eu plasmado a tudo o que fui ou serei. A minha vida entendo-a na iluminação em que me sinto, me estou vivendo, me sou. E é possível por isso que a todo o meu passado eu o esteja reinventando sem saber, como se ele fosse inimaginável fora de como o estou vendo. E a que propósito afirmo, agora, aqui - não aqui: lá? (FERREIRA, 1992, p. 24)

O valor da experiência é que o define, no momento exato em que vive, é o "estar sendo", não necessariamente aquilo que "é". O valor intrínseco da existência - ou o seu sentido, buscado pelo narrador - residiria nele mesmo. Talvez por isso, reinvente seu passado à medida que o viva outra vez, e só assim existiria de fato. Mas as perturbações das dúvidas seguem em todo o percurso, caracterizando mais uma aproximação com o sentimento do absurdo. Como diria Camus (2010, p. 20), "começar a pensar é começar a ser atormentado." Ainda mais: "uma obra absurda não dá respostas" (CAMUS, 2010, p. 112).

Adalberto passa a tomar conta da livraria que era de seu pai, enquanto a mãe ainda está doente; dentre os três empregados, estava Aida:

[...] Escrevo teu nome e estremeço. Subitamente, a tua face... [...] e a tua mão como uma flor... um anel com uma pérola e uns dedos longos e brancos, dedos puros. A mão pousa-se na secretária, os dedos erguem-se em curva lenta até o bico das unhas. Uma intimidade cálida, como um segredo ilícito na nuca. Afloro as tuas linhas, afila-se-me um desejo sutil e 
paralisante - reflexo de vibração num arrepio de pele... Mão de aroma. Ainda agora a aspiro, sinto-a como um rangido ao longo da coluna... Tomo-a bruscamente na minha, a fronte pende-me sobre a mesa. Trituro-lhe os dedos uns nos outros - céus! Como o prazer pode ser insuportável! (FERREIRA, 1992, p. 33)

O ritmo e o tom lírico dessa descrição captam um momento específico na memória de Adalberto e, com uma precisão de detalhes tão expressiva, que trazem de volta a mesma sensação de outrora, mesmo estando preso exatamente por ter matado Aida. De acordo com Camus, "para o homem absurdo não se trata de explicar e resolver, mas de sentir e descrever" (CAMUS, 2010, p. 98). Dizer-se, no início do romance, que o narrador-personagem matou alguém não seria algo por si só horrível, já que se sabe que o discurso é ficcional; no entanto, mostrar a necessidade do ato extremo e os seus porquês no âmbito pessoal parece, isso sim, o fator capaz de promover o reconhecimento da precariedade da condição humana. A doçura da descrição acima, associada à brutalidade de matar quem, supostamente, ama-se, soaria como uma contradição aparente, já que não se trata de ciúme. Apesar disso, para Camus:

[...] Na condição humana, e isso é o lugar-comum de todas as literaturas, há uma absurdidade fundamental ao mesmo tempo que há uma implacável grandeza. Ambas coincidem, como é natural. Ambas se refletem, repitamos, no divórcio ridículo que separa as nossas intemperanças da alma e as alegrias perecedouras do corpo. $\mathrm{O}$ absurdo é que a alma desse corpo o ultrapasse tão desmedidamente. (CAMUS, 2010, p. 129)

É justamente no jogo de oposições e de contradições da personagem Adalberto que se representa o absurdo conforme caracterizado pelo ensaísta francófono. Percebese que essa descrição amorosa não se sustentaria por muito tempo, já que é implacável o desejo de Adalberto em ser outro, em sentir-se vivo no outro e, só assim, poder ser ele mesmo. É como se ele não pertencesse ao todo e só na comunhão com outrem pudesse encontrar-se; no entanto, a solidão se torna cada vez mais aguda. Num diálogo com Aida, ele tenta explicar seus anseios:

Mas não é fácil dizê-lo. Porque as verdades profundas, o apelo do sangue, só se explicam na linguagem da loucura. Ser eu em ti, que um filho nos fosse a nós, que alguém nos existisse, não apenas na memória, mas na força total de sermos - tudo isto é verdade e não tem sentido nenhum. Tudo isto é verdade, porque a solidão é tão estúpida... Aluciname o absurdo como um labirinto: como ser eu nos outros? Ser irredutível e múltiplo? Mas só assim a solidão deixaria de existir. Que me importa transmitir aos outros que dois e dois são quatro ou mesmo o que se passa no fundo de mim? O que eu queria era ser eles quando estão pensando que dois e dois são quatro. O que eu queria é que eles sentissem o que eu sinto e não o que eles sentem. O que eu queria é que eles fossem eu e eu eles, porque só assim é que a "comunicação" tem sentido. Decerto, tudo isto é absurdo - estou farto de o saber. Mas o mais absurdo é o mais humano... (FERREIRA, 1992, p. 38)

O problema é estar só em si mesmo e não poder ultrapassar essa condição. O sentimento do absurdo se dá pela impossibilidade, em última instância, de se relacionar com o outro; mais que isso, de ser ele mesmo no outro. É condição que parece ir além do narcisismo, de vez que se traduz na necessidade de comunicar e aplacar a solidão, em fazer os outros sentirem o que ele sente. Em Camus, os sentimentos mais profundos significam sempre mais do que se pode dizer. Já para Ferreira, na condição de ensaísta, a solidão "é sermo-nos ao máximo no ser-com" (FERREIRA, [19_], p. 118). ${ }^{7}$ O narrador afirma que, dentro dele, só há ele mesmo, e é dessa solidão absoluta que o absurdo nasce. No plano do pensamento de Camus, o sentimento do absurdo está ligado a essa clarividência; é pela consciência do confronto e da impossibilidade que se instala o sentimento. Em Estrela polar, o crime também soa a consequência de um tal quadro, não obstante, no plano da expressão, veicula-se sob um véu, ainda que se possa afirmá-lo, já que o narrador informa, de início, que matou e está preso por isso.

Inquietado por uma indagação sobre a existência de Deus, Adalberto responde:

Porque ninguém pode ser em vez de nós - nem Deus. E esse é o limite radical da nossa solidão. Ainda que fosse possível sabermos tudo de alguém e alguém tudo de nós, seria ainda impossível que nós fôssemos esse alguém e esse alguém nos fosse a nós. E só neste absurdo a solidão não seria. (FERREIRA, 1992, p. 101)

O homem está condenado a ser só; nem a existência de um deus seria suficiente para conferir a ele a possibilidade de ser o outro, o absurdo que aplacaria a solidão na visão de Adalberto. Ser só, estar só no mundo, também é uma

\footnotetext{
Buscando lastro na filosofia de Heidegger, Mendonça afirma: "[...] a relação existente entre os romances Aparição e Estrela polar é a mesma que existe entre os sintagmas estar-sendo e ser-com-alguém." Adalberto, nesse quadro, procura "a pessoa que habita nos outros", expressandose, por isso, "num tu" (MENDONÇA, 1978, p. 62). Indo além - e ainda articulando os dois romances em pauta -, a crítica conclui: "Em síntese, o processo relacional de Aparição e Estrela polar baseia-se no fato de $[\ldots]$ este ser uma espécie de continuação daquele. De fato, os problemas propostos na pessoa de Alberto [protagonista de Aparição] só se completarão na pessoa de Adalberto. A justificação da existência do Dasein só [é] possível na medida em que este é um Mitsein: Alberto procura descobrir quem é, Adalberto completa a questão tentando saber para quem é." (MENDONÇA, 1978, p. 65)
} 
conclusão a que chega Camus, para quem um mundo que se possa explicar, mesmo com raciocínios errôneos, é um mundo familiar. Entretanto, num universo repentinamente privado de ilusões e de luzes, pelo contrário, o homem se sente um estrangeiro. É um exílio sem solução (CAMUS, 2010, p. 21).

Em Estrela polar, o homem é um estrangeiro do mundo e dele mesmo, sente-se incapaz de transgredir essa condição. Por essas razões, Adalberto busca obsessivamente sublimar-se no outro, aspecto inerente ao homem absurdo de Camus, que quer "penetrar em todas as vidas, experimentá-las em sua diversidade" (CAMUS, 2010, p. 82), justamente pelo desejo de "multiplicar o que não pode unificar" (CAMUS, 2010, p. 79). O homem absurdo esgota suas possibilidades no outro; Adalberto tanto o é que, sem razão palpável (ao menos, no que diz respeito a um senso comunitário), deixa de amar Aida - se é que a amou, indagação que ele faz a si mesmo na esfera narrativa.

É o caso, ainda mais, de não se esquecer de que, no sentimento do absurdo, não se exclui a razão, apenas se incorpora o irracional, já que a vida e o mundo em si carecem de explicações lógicas. Tanto assim parece ser em Estrela polar, que Adalberto afirma: "... a verdade é amor, Alda. Aparece e desaparece, quando? Como? Não sei." (FERREIRA, 1992, p. 84). Antes mesmo de encantarse pela irmã gêmea de Aida, Adalberto já evidencia sua crença na fragilidade dos laços humanos, já não há um "núcleo duro" que sustente a existência; a verdade reside no agora, no sentir. Na efemeridade do tempo, não se poderiam criar verdades tácitas, imutáveis. Adalberto continua: "Ser vivo é saber-se vivo. [...] Mas eu quero mais: a minha presença em alguém, a minha duração em alguém... Estamos todos cheios do nosso dom. Mas não se é rico numa ilha solitária." (FERREIRA, 1992, p. 87).

Eis que surge uma mudança de direcionamento no desejo do atormentado Adalberto. Alda, irmã gêmea de Aida, apresenta-se com uma profundidade que, no início da narrativa, o narrador-personagem fora incapaz de perceber. Atentara, tão somente, para o fato de ambas serem extremamente semelhantes, a ponto de confundirem-se uma com a outra. Com Aida, Adalberto chega à conclusão de que "a comunhão perfeita era um mito da nossa pobre solidão. E que se ela se estendesse à humanidade, seria ainda uma solidão de bilhões. Porque só se está unido perante o que nos transcende. Mas nada estava acima de nós..." (FERREIRA, 1992, p. 94). O amor de Adalberto se acaba porque a condição de seu "amor" é ele mesmo, não o outro; inexiste troca - Adalberto se esvazia do outro pela impossibilidade de ser o outro, única forma de lenificar a solidão. Como agravante, revela-se ausente algo que o transcenda, como um deus que pudesse promover a conjunção. Camus afirma que "há gente que é feita para viver e gente que é feita para amar" (CAMUS, 2010, p. 78). Adalberto esgota suas possibilidades de vivências em Aida, e ela passa a não servir mais, o que evidencia o desamor. $\mathrm{O}$ homem absurdo deseja experimentar o máximo de sensações possíveis em simultaneidade, mas, segundo Camus, todas são indiferentes: "Sentir o máximo possível sua vida, sua revolta, sua liberdade, é viver o máximo possível. Onde reina a lucidez, a escala de valores torna-se inútil." (CAMUS, 2010, p. 67). Adalberto não se importa com os valores morais estabelecidos socialmente, tanto assim é que não há tempo entre ele "deixar" Aida e desejar explicitamente Alda, causando, inclusive, reprovação tanto desta, quanto do pai das gêmeas. É como se a vida, num universo em que o homem se sente um estrangeiro, significasse "apenas a indiferença pelo futuro e a paixão de esgotar tudo o que é dado" (CAMUS, 2010, p. 65). Mais uma vez, a reflexão do autor francês parece iluminar a compreensão do caminho trilhado por Adalberto em Estrela polar.

Constrangido pelas circunstâncias, Adalberto passa a sentir mais uma vez um apelo profundo "de dádiva, de comunhão" (FERREIRA, 1992, p. 110); agora, em relação a Alda. Numa conversação com a personagem Garcia (um pintor, para dizer-se o mínimo, instigante), Adalberto ouve as seguintes palavras:

Trata-se de uma "comunhão" e essa comunhão não chega: é preciso uma terceira testemunha. [...] Já pensaste que o celebrado "triângulo amoroso" é afinal isso mesmo? O homem é um verme. Prefere que o esborrachem, a aguentar nada sozinho. (FERREIRA, 1992, p. 136)

Posto que Adalberto se irrite ao ouvir o que o outro lhe tem a dizer, pode-se vislumbrar, no diálogo, uma possibilidade de explicação para a postura do protagonista - tanto se debate por sentir-se sozinho e, quando se vê no outro (como em Aida), ainda que por pouco tempo, depara com a solidão retornando ao ponto inicial, sendo necessária uma terceira pessoa que o afirme. Aqui, não se pode desprezar a condição móvel da alteridade; ou, como disseram Dias \& Pitteri (2010, p. 1): “[...] o Outro é essa instância cujo modo de ser é o próprio devir e, assim como o $\mathrm{Eu}$, propõe-se como identidade móvel, permutável, em busca de afirmação.” A busca se mostra ainda mais improfícua por mudarem tanto o eu quando o tu (ou, na visão de Adalberto, o vós). Muito por isso, sem resposta definitiva permanecem as indagações que Mendonça identifica no romance:

Em Estrela polar, [a] abordagem direta do eu amplia-se ao reconhecimento do $e u$ através do $t u$, ou seja, através do diálogo das aparições [referência 
a Aparição]. Se para aquém de nós existe um halo fulgurante e, todavia, só raramente iluminado, que é sermos metafisicamente, quem será a testemunha dessa presença de aparições e do seu diálogo? Quem é testemunho desse encontro? Quem convalidará o diálogo, a integração perfeita de dois em um? (MENDONÇA, 1966, p. 127)

Alda, duplo de Aida, encaixa-se perfeitamente nas projeções irrealizadas de Adalberto; o que ele não logrou encontrar em Aida, em Alda, revela-se. E experimentaria as duas, tanto que chega a referir-se a elas no romance como Aida-Alda. ${ }^{8}$ Já que a comunhão perfeita é uma ilusão da solidão humana, e não é possível ser o outro inteiramente, "multiplica[-se] aquilo que não [se] pode unificar" (CAMUS, 2010, p. 79). Num determinando momento da narrativa, Aida se passa por Alda para provar a Adalberto o desdém do amigo. Ele tem Alda em mente: "De um golpe olho-a para lhe dizer tudo, para negarmos ambos a irmã, para a assassinarmos, para sermos enfim, um só homem e uma só mulher sobre a terra" (FERREIRA, 1992, p. 215), e, ao tocar a contraparte, o rosto dela muda. Adalberto, assim, percebe tratar-se de Aida, que replica: "Estás convencido agora? Sabes agora que não sou nada para ti? Sou Aida, eu! A que te deu prazer e tu podias amar, se eu quisesse! Mas tu, tu quem és? Quem os outros para ti? Não há confusão nenhuma entre mim e Alda. Porque eu sou eu!"' (FERREIRA, 1992, p. 217)

Aida parece conhecer-se inteiramente e bastar-se; o oposto de Adalberto, julgado por Aida como aquele que não sabe nem quem é, tampouco o que representam os outros, como uma espécie de egoísta ou egocêntrico que não enxerga ninguém além de si. Aqui também fica evidente a possibilidade de Aida fingir ser outra e convencer Adalberto disso, o que se revela no desfecho da narrativa. Além disso, vale pensar na série: AdalbertoAdélia-Aida-Alda; é inevitável observar a proximidade dos nomes e uma possível ironia na escolha, nomes são tão parecidos gráfica e foneticamente e, ao mesmo tempo, tão unidos e tão afastados. O nome de Adalberto contém o de Alda e, no nome de Adélia, está presente o de Aida. ${ }^{9}$ Propositalmente ou não, Adalberto deixa e mata Aida, assim como Adélia o deixou e o mudou. Além disso,

\footnotetext{
8 A propósito, percebeu Mendonça: "O artifício de separar duas pessoas por um traço [...], traço que se institui como o limite da interrogação, ou limiar da loucura consciente, e de alterná-las na vida dum indivíduo (Adalberto) possesso de se apoderar da substância de outrem, proporciona ao Autor a oportunidade de se pôr no caminho do ensaio filosófico." (MENDONÇA, 1966, p. 134). Para o crítico, marcante é o percurso de Ferreira que vai da narrativa ficcional até ao ensaio.

9 Lind já notara certa recorrência, na obra de Ferreira, da personagem masculina dividida entre o amor de duas mulheres; e, mais, de mulheres de nomes semelhantes. O crítico menciona, além da díade Aida-Alda, Hélia e Helena, de Rápida, a sombra (LIND, 1986, p. 43). Ainda sobre o jogo triangular de nomes e de sentidos em Estrela polar, cf. Mendonça (1978, p. 68-70).
}

Adalberto encanta-se por Alda e acredita ter casado com ela.

Conforme sinalizou-se, a disposição narrativa de Estrela polar não é linear - até mesmo as vozes se confundem, muito por o narrador não ser capaz sequer de distinguir Aida de Alda (cabe relembrar que apenas ele as confunde; as demais personagens, não). Também expressa várias dúvidas sobre o conteúdo do que ele próprio diz. É, no fim de contas, a rememoração de um homem que é tudo; menos, centrado. No sentido de tentar compreender o seu próprio narrar, Adalberto acaba por revelar os desvãos de seu pensamento e de seu discurso:

E eis que no dia seguinte - ou um ano depois? Porque, quanto tempo de relógio durou aquilo que narro? O meu amor por Aida e o cansaço disso não podiam ter durado dois ou três meses apenas, como creio ter já dito. Se o que somos, profundamente, explode em revelação, o que o fez germinar não se realizou tão depressa. Sei por exemplo que no meio da minha história há uma imagem numa praia e o corpo de Aida, glorioso de sol. Vejo-a em pé e de perfil, sacudindo os cabelos, os olhos cerrados a um prazer de haustos longos. Ora ela não morreu nesse verão. [...] Um ano pelo menos deve pois haver de permeio - onde? Em que ponto exato desta história? E acaso tem isso interesse? Uma história vivida não tem tempo de calendário - tem-no só no que se viveu. Amei Aida, aborreci-a. E é só disto que falo. Podia inventar uma exatidão, dizendo, por exemplo, que "meses se passaram". Mas uma história que se vive não cabe em três palavras. (FERREIRA, 1992, p. 147)

Adalberto pergunta-se se há verdade humana simples e fácil além de sua loucura; não encontra resposta, o que é usual em toda a narrativa. E as descrições são bastante frequentes - as ruas, a cidade, tudo parece fluir de acordo com emoções da personagem. Sobre Penalva, chega a dizer: "Ó Penalva, cidade aérea, aberta de espaço para todo o lado e tão como esta prisão. Mas eu era dali, da sua imobilidade eterna, da sua condenação eterna." (FERREIRA, 1992, p. 229) Mais uma vez, o romancista parece convergir para os procedimentos em que Camus identifica o absurdo; diz este que descrever é a "suprema ambição de um pensamento absurdo", porque "tudo começa com a indiferença clarividente" (CAMUS, 2010, p. 98). A possibilidade da distância - inerente, por vezes, ao ato de descrever - encontra no pensamento absurdo a realização de uma indiferença que não é motivada passionalmente, mas racionalmente trabalhada por meio do preciosismo das descrições. Camus fala numa "suprema ambição", precisamente pelo fato de, excluindose o transbordamento afetivo, ser possível descrever os detalhes mais recônditos, espaciais ou emocionais, com a devida clarividência intrínseca ao sentimento do absurdo. 
Sobre o estatuto da arte, questão fecunda na ficção e na ensaística de Ferreira, o romance em questão assume (o que também é de uso no projeto do autor) uma feição provocadora:

E que era tudo na vida, afinal? Bom, a arte. Talvez. Mas que era a arte senão um prazer onanista? Saber que os outros gozam também, em que é isso uma união? Um entendimento? Imaginasse eu uma mulher num tablado e uma multidão de espectadores, curvados, metidos para dentro, secretos, doentios, a masturbarem-se. [...] Dizia só que a 'comunhão' na arte era um vigário. Amava a solidão absoluta, porque amava a vida exatamente como ela era. Não a chorava, não cantava o fado. Também ninguém chorava por não ter asas para voar ou por não ter rabo para sacudir a mosca no verão. (FERREIRA, 1992, p. 142)

A falta de comunhão humana é extremada ao ponto de não haver possibilidade sequer da manifestação artística, ficcional ou imaginária, que pudesse promover a conjunção entre os homens. Sobre a questão, Camus afirma que consistiria em erro acreditar que a obra de arte possa ser considerada um refúgio diante do absurdo.

Ela é em si mesma um fenômeno absurdo e a questão é apenas descrevê-lo. Não oferece uma saída, para o mal do espírito. É, ao contrário, um dos sinais desse mal, que o repercute em todo o pensamento de um homem. Mas, pela primeira vez, tira o espírito de si mesmo e o coloca diante de outro, não para que se perca, mas para mostrar-lhe com um dedo preciso o caminho sem saída em que todos estão comprometidos. (CAMUS, 2010, p. 99)

Entendendo-se as conjunturas diversas que veem nascer $O$ mito de Sísifo (com a Europa em guerra, nunca é o caso de se desprezar) e Estrela polar - bem como o gênero distinto a que se vinculam, mesmo com o flerte do romance com o ensaio -, parece haver uma convergência entre o pensamento de Camus e o de Ferreira, no sentido de a obra de arte não se tornar uma resposta, ou uma saída, para as angústias humanas, seja ela a da solidão inexorável, seja a do absurdo do mundo, ou ambas. $\mathrm{Na}$ arte, como o próprio Ferreira afirma noutro texto: "Se é possível a comunicação, não o é decerto a comunhão." (FERREIRA, [19_], p. 117). Em Estrela polar, Adalberto é tão inadequado à vida e tão descrente das relações humanas, que chega a dizer: "A vida é de mais para mim [...]. Reparti-la com alguém, ser comparticipante dela para o passado e para o futuro. Mas o que nos é fundamental ninguém mais o saberá. Ninguém pode sentir por nós nem sequer uma dor de dentes." (FERREIRA, 1992, p. 63). Nas palavras de Camus, "o absurdo fixa seus limites, porque é impotente para acalmar sua angústia
[...] o absurdo é a razão lúcida que constata seus limites." (CAMUS, 2010, p. 56).

No decorrer da narrativa, Adalberto, depois de um período sem ver nenhuma das irmãs, reencontra Alda nas ruas de Penalva, tenta expor a necessidade de participarlhe muitas coisas, até que consegue dizer: "Você é tão bela." (FERREIRA, 1992, p. 221). A resposta de Alda é categórica, e o diálogo que se segue, esclarecedor:

- Mas, Adalberto, a piedade é humilhante. Como o não sabe você? De resto, não sou piedosa. Teria pena de o ser, pena pelos outros. Por isso o não sou.

- E todavia não é a piedade que eu quero, não é.

- Ah, sabe lá você o que quer, sabe lá. Sei tudo por Aida; não sabia que sabia?

Sim. Mas como não ser verdade esta procura? Mesmo através dos meus erros, da minha aberração? Sei que me iludo - tu mo irás dizer. Sei que não amo ninguém, que o amor dos outros é o meu amor por mim, sei tudo o que quiseres, menos acreditar e sentir que é assim. Custa estar só e é impossível por isso que um homem nasça para estar só. Sou de mais para mim. Se tu o soubesses...

- ... Se você o soubesse...

- Mas você não me é nada, Adalberto. Compreende bem? Não sou piedosa, nunca fiz parte de obras pias. E só não há piedade, talvez, quando a piedade é mútua. Mas eu não preciso da piedade de ninguém. (FERREIRA, 1992, p. 222)

Pode-se depreender mais uma confirmação de que Adalberto não é capaz de amar de fato outra pessoa, e o que persiste nele é uma procura incansável por alguém que cure sua solidão sem cura. No entanto, a verdade é que ele deseja algo além de si, que o transcenda. Mesmo sabendo que a busca é vã, continua a fazê-lo. Diz Camus sobre procedimento como o de Adalberto: "Esta lógica é absurda, mas é o que se necessita." (CAMUS, 2010, p. 107). Sobre a piedade, diz o autor francófono: "Também temos às vezes piedade de nós mesmos. É a única compaixão que nos parece aceitável." (CAMUS, 2010, p. 91). Afinal, se o homem absurdo não tem um deus, não consegue transpor a si mesmo, nem mesmo através do amor ou da arte - e, ademais, tem total consciência da finitude de sua liberdade -, apenas ele, em sua clarividência singular, poderia apiedar-se de si. Os que não tivessem essa consciência da absurdidade da vida e da "estranheza do mundo" estariam livres do pesar de saberem-se condenados.

No desenvolvimento do enredo de Estrela polar, virão à tona o que se pode considerar os eventos-chave do romance. Alda e Aida viajam com a família à praia, e Adalberto resolve ir também: "Fui oito dias depois deles. Naturalmente, ninguém sabia da minha ida, apareci de improviso numa manhã de praia, vestido ainda 
de província [...]." (FERREIRA, 1992, p. 229). Nesse momento, Aida comporta-se de maneira desembaraçada e chega a caminhar na praia junto a ele, à irmã e a um rapaz que parecia ser uma nova companhia. No mesmo dia, à tarde, Adalberto cai no sono. Acorda ao entardecer, com um barulho na rua de pessoas gritando. Sai de seu quarto para saber do que se passa e vê um barco no mar revolto explodir. A personagem, então, chora e, no meio do turbilhão, vê Aida nadando entre as ondas. A mulher é levada para o hospital e, quando acorda, olha para Adalberto e diz: “- Ó Adalberto, é tudo tão... É impossível, é impossível... Ainda de manhã Aida me disse..." (FERREIRA, 1992, p. 235). Adalberto passa, então, a acreditar que fora Aida a morrer, e não Alda.

Depois de sepultados os pais e "Aida", Adalberto e "Alda" voltam a Penalva. Ela se isola, deseja sair da cidade, mas Adalberto insiste em que permaneça, até que um dia ela se dirige à livraria e diz que podem casar-se quando ele assim o desejar. É o que sucede. A essa altura, confessa Adalberto: "Imediatamente recomeçou o meu desassossego. Nós estávamos realmente sós e é isto que eu clamo a toda a força, para que enfim me compreendam. [...] Ah, tudo isto é absurdo, tudo isto é de mais, mas só o que é de mais é que é bastante..." (FERREIRA, 1992, p. 259) Mesmo realizando seu desejo de ter Alda, Adalberto volta a se sentir só, e esse absurdo de sua incapacidade de "viver com" o leva aos extremos. O que é demais, nunca é o bastante para ele, uma vez que vive sempre do que é "de mais", e nunca se satisfaz. Interpelado pelo juiz que julgava seu crime sobre se reconhecia ter se cansado da esposa, Adalberto responde: "- Não me 'cansei': ela é que se gastou. Eu estava só. Mas quem é que quer estar só? Ninguém quer. Tenta-se sempre mais e mais. Até ao fim." (FERREIRA, 1992, p. 260) Citando o "dom-juanismo" como uma expressão do homem absurdo, Camus anota: "Amar e possuir, conquistar e esgotar, eis a sua maneira de conhecer.” (CAMUS, 2010, p. 79). É bem um traço que se pode flagrar no narrador-personagem Adalberto. Sobre o amor de "Alda", chega a dizer: "-Amar é conhecer e consentir. Mas só se conhece e se consente o que tem limites, o que é humano. Tu queres a desumanidade e o excesso." (FERREIRA, 1992, p. 265) A resposta de Adalberto é perguntar-lhe se ela nunca quis tal coisa.

Então "Alda" avisa que terá um filho, notícia que deixa Adalberto completamente desnorteado. Ao nascer o bebê, verifica Adalberto:

[...] Ao debruçar-me sobre o berço, aquela coisa pequena, avulsa, fragmentária, paralisou-me de terror: esse bicho flácido e esfolado, esse bocado de carne olhava-me... Fascinado, ali fiquei longo tempo, fitando-o, fitando-o: quem és tu? Que vem dentro de ti? Como me apareces aqui, inesperado, tu à minha face? (FERREIRA, 1992, p. 274)
Adalberto expõe uma inadequação tão absoluta à vida que sequer a existência de um filho seu é capaz de compreender; ou, de alguma forma, sentir-se finalmente no outro, ser o outro, já que seu desejo primeiro, desde o início da narrativa, é esse. No entanto, o que fica claro é que nada realmente será suficiente para ele. Tudo é demais e nada basta. Os amores, a família, a vida... até um filho. Nada confere sentido ou gera resposta ao homem atormentado, para sua luta sem trégua, para sua confrontação; fatores que remetem ao sentimento do absurdo. Pouco depois, na sucessão dos eventos da narrativa, "Alda" revela para Adalberto que é, na verdade, Aida:

Não me enganara - dizia só para si, conversando com o espectro de si própria. Quando chegara à praia dissera o meu nome impessoal: que éramos nós então um para o outro senão impessoalidade? Mas vira meu engano e acentuara-o, esperando. E custava-lhe tanto perder-me. Além de que eu podia descobri-la enfim. E se eu a não descobrisse poderia ela revelar-se no seu nome, num ajustamento de sons, na alteração de uma letra, quando a vida nos unisse, quando eu me reconhecesse no que Aida era. Esperança vã: eu amava-a, não a ela, mas a quê? (FERREIRA, 1992, p. 290-291)

Para Camus (2010, p. 104), "uma atitude absurda, para continuar sendo tal, deve manter-se consciente de sua gratuidade, tal como a obra." Adalberto expressa mesmo essa gratuidade em seu desamor por Aida, por Alda, pela própria mãe, que morre no início da narrativa; nem ele mesmo sabe o que ama e se ama. $\mathrm{O}$ romance exalta justamente esta ilogicidade da vida e dos sentimentos, a comunhão entre duas pessoas como uma impossibilidade. É verdade que se classificar a obra como absurda, à luz da problematização de Camus, soaria a redução, uma vez que o próprio ensaísta reluta em definir o termo; entretanto, é patente, em Estrela polar, a exposição do sentimento de absurdo por meio da personagem Adalberto.

Outro aspecto desta absurdidade da personagem pode ser encontrado no momento em que seu filho morre ainda bebê, por sufocamento. Adalberto chega a dizer que ficou "quase feliz", e considera imoral o choro de Aida, irritando-se, inclusive. Nas palavras "quase bela, a morte" (FERREIRA, 1992, p. 297), o desprezo de Adalberto por Aida se revela ampliado. É então que recebe um conselho de Garcia: matar a consorte. O protagonista fica tentado, pensa na pistola que comprou, devaneia sobre uma razão para cometer o ato extremo. Eis que acontece uma espécie de atropelamento na rua, e Aida segue com Adalberto para o hospital; lá, ele a estrangula com as próprias mãos, o que lhe renderá a pena de vinte anos de prisão. Declara: “[...] a morte é o signo do meu excesso." (FERREIRA, 1992, 
p. 318) De acordo com Camus, "[...] o absurdo comanda a morte." (CAMUS, 2010, p. 24). Adalberto encontra na morte uma espécie de prazer e libertação, já que ele, de algum modo, admira-a. Para Ferreira, em condição de ensaísta, a importância da morte deriva da importância da vida (FERREIRA, [19 ], p. 81). Ora, Adalberto tem consciência de sua vida, mesmo sem compreendê-la, tanto que se esforça para esgotar suas possibilidades de estarno-mundo. Como diria Camus, "aquilo que lhe provocava desespero quanto ao sentido e à profundidade desta vida, lhe dá agora sua verdade e sua clareza" (CAMUS, 2010, p. 47). É assim que Adalberto se sente diante da morte. Segundo o romancista:

[...] Antecipando-se a si, o homem descobre a morte como limite, e pode antecipar o vivê-la, o enfrentá-la. A morte surge assim como o último possível numa sequência de possíveis. E como a morte, sendo a última possibilidade inultrapassável, certa, embora indeterminada, é simultaneamente a única situação, verdadeiramente única, em que o homem está só (Pascal: on mourra seul), ela representa a melhor prova de uma autenticidade. O homem é, pois, um serpara-a-morte, por ser a morte o limite de uma cadeia de possíveis, e ainda porque o futuro nos esclarece o presente, nos determinamos não de hoje para amanhã, mas ao invés, já que o homem é antecipação de si. (FERREIRA, [19_], p. 83)

A morte seria então uma última possibilidade a esgotar, assim como tudo na vida de Adalberto, mas no outro, como sempre o foi, não em si mesmo. Do contrário, ele teria matado a si, mas, como se traduz no discurso de outras personagens (filtrado, no romance, pelo do narrador), Adalberto só amava a si mesmo. A vida e tudo o que ela traz era demais para ele. Como várias vezes se revelou no escopo da narrativa, a clarividência que Adalberto tem da ilogicidade de tudo o conduzia ao mesmo lugar de sempre: sua solidão irredutível. Do pensamento de Camus, é possível extrair-se a ideia de que o homem absurdo sabe, na sua consciência atenta, da inexistência de lugar para esperança.

Por fim, sobre o título do romance, o narrador elucida:

Talvez se eu pusesse um outro título a esta história. Por exemplo 'O Traidor'. Ou 'O Criminoso'. Duas palavras breves negando e moralizando os milhares de palavras em que me comprazi. Chamo-lhe apenas 'Estrela polar', porque sou mais corajoso ou o desejo parecer. Luz breve, que existas, onde? Fugidio indício que me anuncie o meu lugar na vida... (FERREIRA, 1992, p. 309)

A estrela polar é aquela que permanece fixa por milhares de anos e é usada desde a Antiguidade como um guia essencial, daí a coragem do escritor-personagem de escolher esse título, já que, em suas mãos, tudo é fugidio, com algumas exceções (sua solidão por exemplo). Talvez, como ele mesmo diz acima, seu desejo seja de um lugar na vida. E, sobre a coragem de contradizer, de certa maneira, sua condição, pode, por isso, ser vinculado a Sísifo, que engana os deuses e é discordante de suas imposições, evidenciando o desejo humano de vencer a morte, a constatação do esforço inútil. Desse quadro, deriva o evidente pessimismo, como forma de realidade inevitável. Também recorrendo ao mito de Sísifo, o próprio Ferreira ([19__], p. 122) escreve: "Sísifo não é ridículo, nem covarde, nem estúpido, porque é grande na sua miséria, porque é corajoso em não desistir, porque é clarividente e sabe que o alto da montanha fica sempre para lá do alto da montanha." Para Camus, Sísifo é o herói absurdo, por causa de suas paixões, de seu tormento, e de sua clarividência, não havendo, assim, destino que não pudesse ser superado com desprezo. Adalberto constata a impossibilidade da comunhão entre os seres e a sua indiferença aos sentimentos dos outros é revelada no máximo de seu desprezo por Aida e até pelo próprio filho. Nas palavras de Camus:

[...] Deixo Sísifo na base da montanha! As pessoas sempre reencontram seu fardo. Mas Sísifo ensina a fidelidade superior que nega os deuses e ergue as rochas. [...] A própria luta para chegar ao cume basta para encher o coração de um homem. É preciso imaginar Sísifo feliz.” (CAMUS, 2010, p. 124)

Estrela polar termina com o narrador afirmando que a série de acontecimentos de sua história não cessará de se repetir, sempre, assim como Sísifo, condenado à repetição dos gestos. Talvez seja o caso de se entender a loucura de Adalberto, aceitar-se sua inadequação e partilhar de sua desesperança; mas, mais que isso, é preciso continuar erguendo a rocha.

\section{Referências}

BARRETO, Vicente. Camus: vida e obra. 2. ed. Rio de Janeiro: Paz e Terra, 1991.

BORNHEIM, Gerd. A. (Org.). Os filósofos pré-socráticos. 14. ed. São Paulo: Cultrix, 2007.

CAMUS, Albert. $O$ mito de Sísifo. Tradução de Ari Roitman e Paulina Watch. Rio de Janeiro: BestBolso, 2010.

CAMUS, Albert. Le mythe de Sisyphe. Paris: Gallimard, 1942.

DENIS, Benoît. Literatura e engajamento: de Pascal a Sartre. Tradução de Luiz Dagobert de Aguirra Roncari. Bauru: EDUSC, 2002.

DIAS, Maria Heloísa Martins; PITERI, Sônia Helena de Oliveira Raymundo (Orgs.). A Literatura do outro e os outros da Literatura. São Paulo: Cultura Acadêmica, 2010. 
FERREIRA, Vergílio. Estrela polar. 4. ed. Venda Nova: Bertrand, 1992.

FERREIRA, Vergílio. Pensar. 6. ed. Venda Nova: Bertrand, 1998.

FERREIRA, Vergílio. Da fenomenologia a Sartre. In: SARTRE, Jean-Paul. O Existencialismo é um humanismo. 3. ed. Lisboa: Presença, [19__].

FERREIRA, Vergílio. Espaço do invisível. 4. ed. Lisboa: INCM, 1987.

FERREIRA, Vergílio. Vagão “J”. 2. ed. Lisboa: Arcádia, 1974.

GRENIER, Roger. Albert Camus: soleil et ombre: une biographie intelectuelle. Paris: Gallimard, 2009.

LIND, Georg Rudolf. Constantes na obra narrativa de Vergílio Ferreira. Colóquio/Letras, n. 90, p. 35-46, mar. 1986.

MENDONÇA, Aniceta de. O romance de Vergílio Ferreira: existencialismo e ficção. Assis: ILHPA; HUCITEC, 1978.
MENDONÇA, Fernando. A Literatura Portuguesa no século XX. São Paulo: HUCITEC, 1973.

MENDONÇA, Fernando. O romance português contemporâneo. Assis: Faculdade de Filosofia, Ciências e Letras de Assis, 1966.

PAIVA, José Rodrigues de. O espaço-limite no romance de Vergílio Ferreira. Recife: Encontro; Gabinete Português de Leitura, 1984.

SEGRE, Cesare. As estruturas e o tempo. Tradução de Silvia Mazza e J. Guinsburg. São Paulo: Perspectiva, 1986.

TORRES, Alexandre Pinheiro. O movimento neorrealista em Portugal na sua primeira fase. Lisboa: Instituto de Cultura e Língua Portuguesa, 1977.

Recebido: 02 de novembro 2013

Aprovado: 29 de setembro 2014

Contato: bezerra.a.c@gmail.com amandabarrospe@gmail.com 